\title{
TRADITIONALISATION FOR REVITALISATION: TRADITION AS A CONCEPT AND PRACTICE IN CONTEMPORARY SÁMI CONTEXTS
}

\section{Coppélie Cocq}

\begin{abstract}
This article investigates the use of 'tradition' as a concept in indigenous discourses and as a label of practices within revitalisation processes, using the case of the Sámi in Sweden as an example. By approaching emic applications of the concept, the article aims at emphasising processual and consequential aspects of 'tradition'.

This study illustrates how traditionalisation takes place through the processes of negotiation of identities, globalisation and authority, as well as through the institutionalisation of vernacular practices. It is a double-edged process, including and excluding, which is balanced with creative initiatives striving for keeping traditions alive rather than frozen in time.
\end{abstract}

Keywords: digital environments, emic discourses, indigenous communities, selfrepresentation, tradition, traditionalisation, vernacular practices

This article investigates the use of 'tradition' as a concept in indigenous discourses and as a label of practices, by examining the case of the Sámi in Sweden. The recurrent and abundant use of the term 'tradition' on Sámi websites and in documents from Sámi cultural agencies and officials has motivated this investigation along with encouragement from the strong theoretical attachment of this concept in folkloristics.

It is not my wish to contribute to the "tradition of talking about tradition" (Noyes 2009: 234). Instead, my aim is to critically analyse the implications and consequences of the use of the term and of the process of traditionalisation in the particular context of Sámi linguistic and cultural revitalisation. Through an overview of the occurrence of the word in online Sámi discourses and in published documents, I examine the labelling of certain practices as 'traditions' in order to problematise the implications of this process. Before addressing these issues, I contextualise contemporary Sámi initiatives in the first section of the manuscript. This is followed by a discussion of the concept in relation to folkloristics, and a discussion of methodological considerations. 
As I show in this article, globalisation, institutionalisation of vernacular practices, negotiation of a contemporary Sámi identity, and related issues of authorisation play major roles in traditionalisation. It is a double-edged process, both including and excluding.

\section{SÁMI REVITALISATION}

The Sápmi area includes the northern parts of Norway, Sweden, Finland, and Russia. The Sámi population, estimated to be about 80,000 to 95,000 individuals, is spread across the four countries, in urban areas as well as in the traditional Sápmi area. National legislations define who a Sámi is, and this definition is based on language ${ }^{1}$ and self-ascription. This geographical dispersion implies disparities in minority politics. Until the Second World War, the Sámi populations in the four countries were subjected to the politics of cultural assimilation (Elenius 2006: 149-249; Lundmark 2008: 141-184). The degree and consequences of this political period for the Sámi in the four countries differed, but the stigmatisation of the Sámi identity has been a threat to the Sámi language and culture. Today the Sámi languages are endangered; some of them even close to extinction. From the mid-1900s, a more favourable ideological climate for the minorities in Europe has allowed for practical measures toward political organisation and cultural revitalisation by the Sámi.

The emergence of national symbols, such as the flag and the national song, took place in the late 1980s, and the Sámi Parliament was inaugurated in Sweden in 1993. This followed the establishment of a Sámi Parliament in Norway in 1989 and preceded the one in Finland in 1996. Although active participation in politics began long before that, the 1970s are referred to as a turning point in Sámi organisational history. The ČSV movement, named after slogans such as Č́ajehehkot Sámi Vuoinya! ("Show the Sámi spirit!") or Čohkkejehket Sámiid Vuitui ("Unite the Sámi for victory") was a new awakening and "became a rallying call for the Sámi people who had a confrontational attitude toward Norwegian society" (Bjørklund 2000: 29). Many other Sámi initiatives followed the ČSV movement as signs of efforts to define Saminess based on the group's own premises and self-representation. There was, for instance, a "renaissance in duodji (handicrafts)"; the gákti (Sámi costume) was 'rediscovered' and became "a way of expressing Sámi national unity", and place names came to "constitute the clearest expression of Saminess" (ibid.: 31-32). Such traditional aspects of the culture are essential markers of the Sámi identity (Ruong 1981).

In the contemporary context, initiatives to strengthen and promote the Sámi languages are encouraged and supported by the political climate that is signifi- 
cantly more favourable than in the 1970s. This improvement has been concretised during the last decades, for example, by the ratification of the European Charter for Regional or Minority Languages as well as by the introduction of local legislation in regard to minority languages in the Nordic countries.

The current state of cultural and linguistic revitalisation (Pietikäinen 2008; Scheller \& Vinka forthcoming) is central in these processes and in the analysis of the uses of the concepts of tradition and traditionalisation. As Scheller \& Vinka (forthcoming) point out: "Benevolent legislation is often a prerequisite [to language revitalization], but matters of implementation are as vital." Further, revitalisation requires changing community attitudes (Grenoble \& Whaley 2006: 13), and the articulation of traditions and the definition of 'the traditional' are parts of these efforts for the implementation of legislation and change.

This article investigates these aspects of cultural production by examining the occurrence and use of the concept of tradition on the Sami websites administrated by educational and cultural agencies, museums, and the Sámi media. This includes online data and documents such as cultural programmes, and official reports from Sámi organisations.

The topic of this article is one that is often covered in folklore studies, but here it specifically concerns the Sámi case. Therefore, an overview of the theoretical approaches within the field is necessary before discussing contemporary examples of traditionalisation.

\section{THEORETICAL APPROACHES AND METHODOLOGICAL CONSIDERATIONS}

For folklorists, a main interest in studying the concept of tradition lies in its potential for the study of the "process of cultural construction" (Glassie 1995: 398). The "traditional' is not an objective property of phenomena but an assigned meaning" (Handler \& Linnekin 1984: 286). Investigation into the processes and performative aspects of assigning meaning to specific traditions give us insight into the factors and forces that interact behind cultural expressions and within cultural contexts. Taking into account social aspects when approaching Sámi traditions is, indeed, a prerequisite for understanding the manifold processes of cultural production (compare Hymes 1975: 353).

Traditions are often discussed in terms of continuity and discontinuity, but it is also important to scrutinise the stability of traditions (Noyes 2009: 239), i.e., the reason why certain practices are maintained and/or reactualised. The nature of the role that these traditions play in a culture, and the meanings assigned to them, deserve investigation. 
Tradition is a powerful concept that has the ability to influence political processes. In the specific context of revitalisation of the Sámi languages and culture, the goals in minority politics and the recurrent use of references to Sámi traditions motivate further inquiry. Such inquiry must bear in mind the consequences that the labelling of practices as 'traditional' has had in the past. The concept of tradition is loaded with connotations because of its uses and abuses in nationalistic discourses (Christophe \& Boëll \& Meyran 2009; Korhonen 2008; Kvist 1992). Academic research was also influenced by the political and ideological attitude toward indigenous peoples and minorities at that time (Cocq 2013a; Deloria 1998; Smith 1999).

In addition to examining the emic uses of 'tradition', this article investigates the process of traditionalisation. In line with Mould (2005: 261), I approach traditionalisation as "the act of explicitly referencing some element of the past considered traditional within the community". Traditionalisation is a self-conscious process (cf. Handler \& Linnekin 1984: 287) that takes place in the community at different levels.

This view of tradition as an analytical concept stresses its power and what it can achieve in terms of defining a culture, categorising communities, or establishing common grounds and boundaries. Based on these theoretical considerations, this article seeks insight into the processes of cultural constructions in a Sámi context and into how these processes strive to generate continuity, discontinuity, and stability.

This study is the offspring of a project investigating the role of the Internet in Sámi revitalisation, which focuses on self-representation and place-making in digital environments (Cocq 2013b) and on the continuity of storytelling (Cocq 2013c). In addition to the study of Sámi websites, empirical data were collected through surveys and interviews in order to include the website users' perspectives. $^{2}$ The results of the survey give us an indication as to the importance placed by the users on the political aims that focus on the significance of passing on Sámi traditions to future generations. The topic of tradition came up during discussions with several consultants. ${ }^{3}$

In line with recommendations in indigenous methodologies, research should focus on the interests, experiences, and goals of indigenous people themselves (Porsanger 2004: 109; Smith 1999: 39). Therefore, the importance given to the topic and how it was problematised by the consultants ${ }^{4}$ in this project has motivated this particular study. More specifically, several consultants identified the constraining effects of normalising discourses about what is right and correct when talking about what is traditional. For instance, a Sámi cultural worker (Consultant 3) was critical of the use of the term: 
'Tradition' is often used in the sense of 'the old days' and applies to something static. For instance, the gákti (Sámi costume) can only look one single way to some people. You can't add something to your gákti that is not 'traditional'.

Another consultant (Consultant 1) commented on the constant quest for tradition that one can experience: "We are bound by tradition...". The same interviewee wished for more innovations in terms of incorporating new elements and practices into an otherwise traditional framework.

Another use of the concept of tradition is as a criterion of authenticity, and this was mentioned by several consultants. The concept is sometimes used in a similar sense with regard to language: as a way to define an 'authentic' language. One consultant (Consultant 3) expressed concern about the ways in which such a view of tradition could "suffocate all that is Sámi", i.e., that such a view could have a negative impact on the dialectal variations of the Sámi languages. The wording and the framing of the concept reflect a perception of 'tradition' as something tangible: traditional practices are described as something that we follow - or choose not to follow - and as something that "we can lose" (Consultants 3, 4, 5).

In order to further investigate the occurrence and use of the concept of tradition in contemporary Sámi discourses, this article examines a range of examples and utterances. The main focus is on Sámi websites from Sámi media, project homepages, information centres, community museums, and initiatives that promote language acquisition. The selection of material was based on the results from the survey of the users of Sámi websites and on observations of the most cited, linked, and mentioned websites. The study of the web pages was conducted through navigation and documentation (video recording) of the websites, with specific attention paid to paths, aesthetics, and intertextuality (how the text of the website relates to other texts or websites). The source of information, the targeted audience, and the coexistence of different voices (for instance, vernacular and official), discourses (public or political), and genres (textbooks, exhibitions, performances, and discussion forums) are other aspects that have been included in the online observation conducted for this study (cf. Hine 2000; Kozinets 2011).

Examples of the emic use of the concept of tradition on Sámi-produced websites, in cultural programmes, and reports from Sámi cultural agencies and officials are discussed in the following section. 


\section{'TRADITIONAL' PRACTICES}

The first part of this study discussed the use of the term 'tradition' and other terms associated with it. The co-occurrence of terms was mapped by reading the texts that had been selected by reason of the frequent use of the terms 'tradition' or 'traditional' ' on the web pages included in the online observation described above. The locating of the occurrences of words associated with the concept of tradition in web environments gives us an indication of the settings in which the term is given specific meaning. The terms 'language', 'knowledge', and 'identity' are frequently used in connection with 'tradition' or 'traditional'. 'Cultural heritage' is another concept that commonly occurs in relation to 'tradition'. The concept of 'tradition' is also often used in association with livelihoods in general, but also more specifically with reindeer herding ${ }^{7}$.

The information site developed by the Sámi Parliament establishes an explicit connection between reindeer herding and tradition:

Reindeer herding is not only a way of achieving an income - it is also the bearer of a long cultural tradition and a Sámi identity. [It] is intimately connected with Sámi culture, and is a tradition that extends a very long way into the past. ${ }^{8}$

Here, reference to the past, continuity, and contemporary identity signifies the traditionalisation of the practice of reindeer herding.

Tradition is frequently used in relation to abstract terms, such as traditional knowledge, values, society, culture, ways of life, customs, etc. ${ }^{9}$ Some more tangible topics are associated with the concept, including buildings ${ }^{10}$ (with reference to constructions used in nomadic times), the gákti, and duodji (handicrafts constructed according to traditional methods and patterns $)^{11}$.

Duodji is based on the use of traditional methods, materials, and techniques. It is an interesting field of elaboration of Saminess, in which negotiation between tradition and innovation takes place. It is also a strong symbol of Sámi identity. There is an official label (see Figure 1) that functions as a certificate of authenticity for artefacts created in line with Sámi traditional methods. Duodji today illustrates how items of everyday use have become pieces of art. The náhppi, a bowl used to collect milk, is an example of how traditional knowledge and cultural affiliation are incorporated into an object. The milking of reindeer is no longer practiced; nowadays, reindeer herding is solely concerned with the production of meat. But the artefact itself is associated with knowledge specific to the community. The visualisation and presentations of artefacts online show how certain objects are highlighted. This is true not only for the náhppi, but also for items like the Sámi knife or the shamanic drum. 


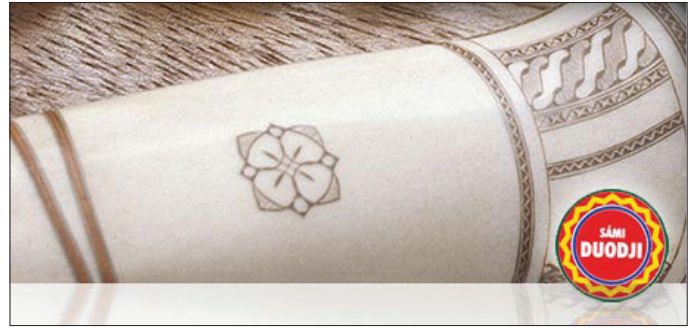

Figure 1. Screenshot of http: / / www.sameslojdstiftelsen.com, the website of the Sámi Handicraft Foundation in Sweden. The logo Sámi Duodji certifies the authenticity of artefacts produced in accordance with Sámi traditions.

In many instances, storytelling is referred to as traditional and in Swedish this is often marked by the compound word berättartradition (storytelling tradition). One example can be found on the Gulahalan website (http://ww4. ur.se/gulahalan/), a site for language acquisition for the beginners of North Sámi. Gulahalan (i.e., "I make myself understood") is produced by the Sámi Educational Centre in Jokkmokk and the Swedish Broadcasting Company, and designed as a textbook, but includes ten recorded narratives that can be used to practice listening comprehension.

The authors of the website are teachers at the Sámi Educational Centre, a community-driven school with educational programmes in language, handicrafts, and reindeer herding. The site is produced in collaboration with the Swedish National Educational Broadcasting Company that has a mandate to produce and broadcast educational programmes and bears national responsibility for providing media in minority languages. Website

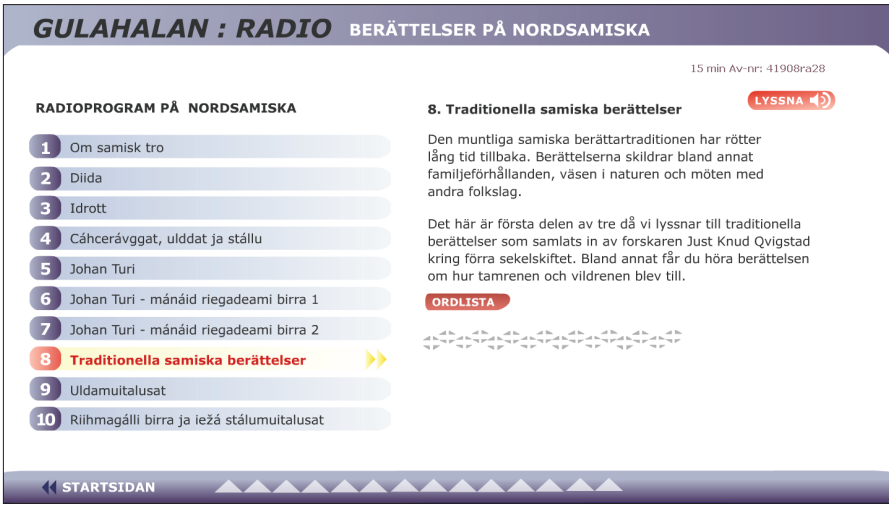

Figure 2. Screenshot of the Gulahalan website (http: / / www4.ur.se/gulahalan/). The text in Swedish begins, "Traditional Sámi stories. The Sámi oral tradition has its roots way back in time", and this is followed by a recording of the story that the web visitor can listen to, information about its source, and a publication from 1928 by lappologist Just Knud Qvigstad (Qvigstad 1928). Two of the other stories are readings from Sámi Deavsttat (Turi 1931), one of the books by the storyteller and Sámi writer Johan Turi. 
visitors are primarily beginners of the Sámi language and the majority are very probably Sámi ${ }^{12}$.

Another website, visitsapmi.com, mentions storytelling as something "in our genes", suggesting that it is a natural way to convey traditional knowledge. ${ }^{13}$ This is a website of a tourism organisation operating in Sweden, Norway, Finland, and Russia, which is created and owned by the Swedish Reindeer Herders Association (SSR) in order to develop tourism based on ethical criteria that counter commercial exploitation. Owners of the organisation are reindeer herding communities and Sámi NGOs operating together with the South Sápmi Information Centre, Gaaltije. The SSR and Gaaltije are also the institutions that run the website. It addresses tourists and prospective tourists as well as other tourist organisations.

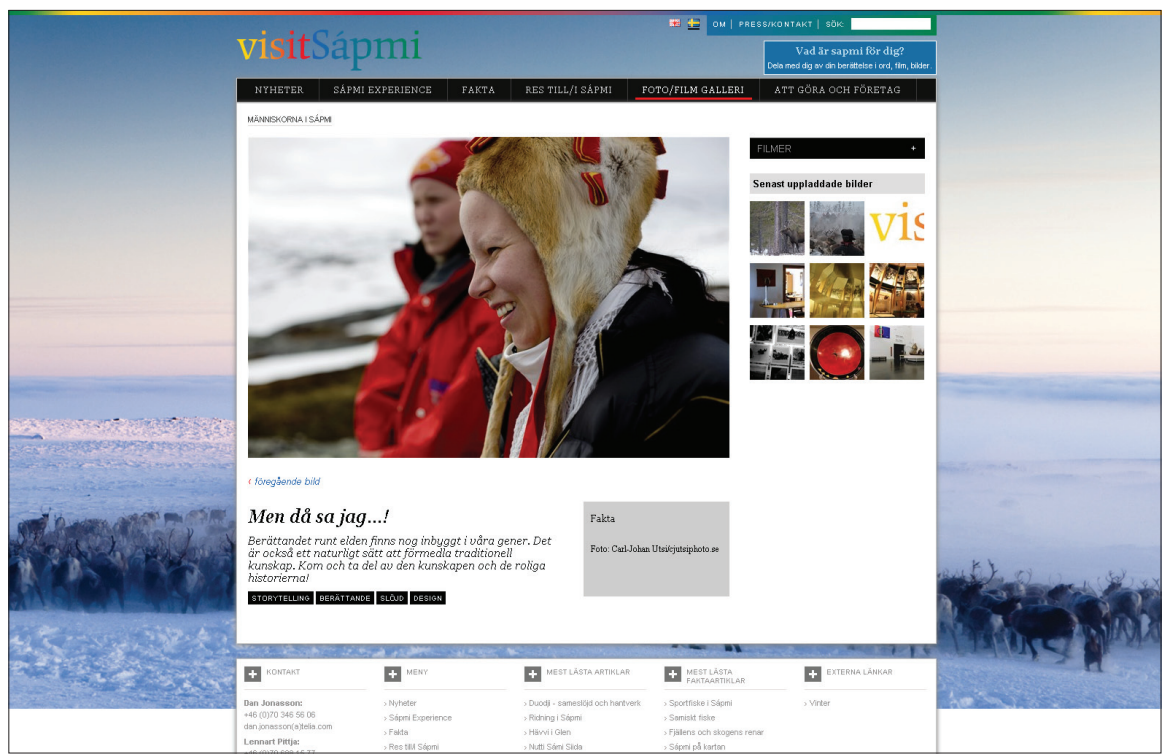

Figure 3. Screenshot of the site www.visitsapmi.com, saying: "Telling stories by the fireplace is in our genes. It is also a natural way to convey traditional knowledge. Come and acquaint yourself with our knowledge and our fun stories." ${ }^{14}$

Food is another example of a notion that co-occurs with 'tradition' and 'traditional', i.e., it is another practice that is labelled as a tradition. There are an increasing number of projects related to cultural culinary practices, and a cooking trend can be observed in numerous television programmes. In an 
international context, this can be illustrated by projects such as Slow food, a non-profit member-supported organisation ${ }^{15}$. In a Swedish context, Renlycka ("reindeer luck", i.e., success in reindeer herding) is a project that encourages and promotes the production of Sámi primary products (such as reindeer meat) and emphasises the deep traditions of processing reindeer meat. All of this is described in detail on the website.

The Renlycka project is owned by the SSR. According to the website, the quality seal Renlycka "signifies that exceptional quality can only be gained through a deep-rooted knowledge of reindeer herding and a unique understanding of nature, human and culture". ${ }^{16}$ The website is currently run by the project owner, the SSR. It addresses not only consumers interested in reindeer meat and other food products, but also food-processing companies and people interested in slow food movements.

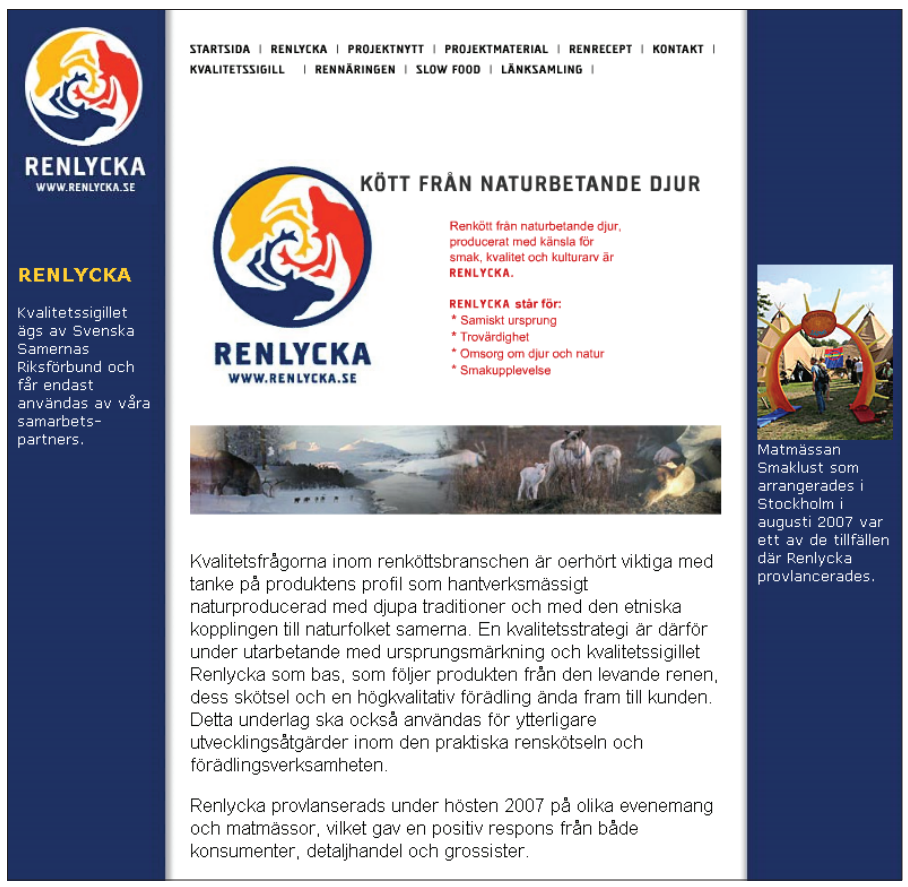

Figure 4. Screenshot of Renlycka.se, saying: "Reindeer meat from freely grazing animals, produced with a feeling for taste, quality and cultural heritage, is Renlycka. Renlycka stands for: Sami origin; credibility; care for animals and nature; pure taste experience." Reference to tradition is stated at the beginning of the text below the picture: "The issue of quality in the reindeer meat industry is extremely important considering the nature of the product as artisanal with deep traditions and its ethnical relation to the Sámi." ${ }^{17}$ 
Traditional cuisine is also one of the categories in a recent competition - Sápmi awards - initiated by the municipality of Jokkmokk as "an investment to praise the Sámi culture and traditions that enrich the region". ${ }^{18}$ The competition contributes to the traditionalisation of practices in the categories of culinary art, music, reindeer herding, and handicrafts (art and design).

Due to the lack of a specific definition for its use, the concept of tradition functions as an umbrella term for different categories of practices or artefacts. Handicraft is a practice associated with local traditions, and its status is emphasised and confirmed by the official label Sámi duodji by the Sámi Handicraft Foundation (Sameslöjdstiftelsen), which certifies the authenticity of artefacts created in line with Sámi traditional methods. As for storytelling, we know about its variations and can estimate how much it has changed over time (e.g., Cocq 2008; Toelken 1996). Legends and tales, as well as the art of storytelling itself as an oral practice, are inherently associated with Sámi traditions. The labelling of specific cuisine as a traditional practice is based on assumptions, and the reindeer is often associated with Sámi ethnic identity. The animal and its herding establish a link to culinary practices. However, not all Sámi are herders; actually only a minority of all the Sámi are engaged in reindeer herding today, and many Sámi communities do not live on herding. It might, therefore, be easy to associate reindeer meat with Sámi ethnicity, but this association is often more symbolic than an indication of current practice.

The ways that the concept of tradition is employed in cultural programmes, documents, and reports from Sámi cultural agencies and officials provide additional information about contemporary uses of the term in cultural and political contexts. This reading allows us to understand "the broader contexts that reveal what a particular group considers 'traditional"' (Mould 2005: 290).

One example of such documents is the programme of activities for the winter market in Jokkmokk, a major annual event in Sápmi. Twenty to forty thousand people, both from Sápmi and from far away, gather in the small town of Jokkmokk in the north of Sweden on the first weekend of every February. The outdoor market is not only an opportunity for buying supplies and handicrafts, but also a meeting place. Cultural as well as social events take place during the week. ${ }^{19}$ The selection of activities that were presented in the programme for the 2012 market indicated an interest in food, storytelling, music, and handicraft, all of which were labelled as 'traditional'. These topics appeared during each day of the seven-day calendar of activities.

In the report for its plan of activities for the year 2011, the Sámi Parliament of Sweden identified the promotion of traditional knowledge as one area of concern in the work of the parliament (Sametinget 2011: 2). "Traditional knowledge" was employed in the singular, and the report did not state what it included. In 
the report on cultural policy, the parliament defined traditional knowledge in relation to a way of life "close to nature" as a marker of identity. Other markers were duodji, language, and kinship (Sametinget n.d.: 5). The definition of culture is based on UNESCO's universal declaration on cultural diversity - a definition that includes traditions (Sametinget 2010; UNESCO 2001).

In a specific report about traditional knowledge, the parliament chose to call this form of knowledge by the North Sámi term árbediehtu (heritage knowledge). The word árbi (heritage) stresses the relation to the past and the continuity of the specific form of knowledge that is being discussed, as well as to the mode of transmission of the knowledge from generation to generation (Nordin-Jonsson 2010; Utsi 2007).

Several other projects financed by national institutions and officials are concerned with Sámi tradition(s), for instance, traditional knowledge about dancing that aims to reveal the "proof of a Sámi dancing tradition" (Stålnert 2011). The Swedish Sámi museum Ájtte has undertaken projects concerning traditional knowledge in Laponia (financed by NAPTEK ${ }^{20}$ and the Sámi Parliament) and the protection of Sámi cultural heritage and cultural traditions (Ájtte 2008). Another example of a project concerned with traditional knowledge was undertaken in 2008 by the SSR called "Mapping the Sámi Cultural Landscape" (SSR n.d.).

These examples illustrate in what ways the term 'tradition' is employed in specific Sámi contexts and what is associated with the concept. It is, to a great extent, used in correlation to cultural aspects for the purpose of emphasising continuity. Reindeer herding, duodji, storytelling, and knowledge are all such aspects of the concept of tradition and have emerged as essential parts of the Sámi culture that has remained stable over time.

As Mould (2005: 257) emphasises, researchers need to distinguish these "conscious and explicit efforts of traditionalisation from inherent or implicit factors that feed or reinforce a tradition". The following sections focus on these implicit factors and processes and their consequences.

\section{TRADITIONALISATION OF PRACTICES: NEGOTIATION OF IDENTITIES AND GLOBALISATION}

The urge to refer to and define traditions and traditional practices is not a new phenomenon. References to traditions can be traced in legends when explaining the origin of some practices. For instance, medical and noaidi (shamanic) knowledge, yoik (narrative Sámi singing), and skills in reindeer herding are said to have been passed on to the Sámi by the invisible beings called ulddat (e.g., Turi 2010 [1910]). This explicit linking of indigenous knowledge to ancestral 
practices of supernatural origin validates current practices. The uses of, and references to, ancient practices in new settings have been studied in previous research, for example, in discussing performative arenas such as food (e.g., Pico Larsen 2011; Schram 2010), sports (e.g., Hafstein 2009), handicrafts (e.g., Hyltén-Cavallius 2007), and songs (e.g., Kuutma 2006).

In a similar vein to Bronner's $(1998,2011)$ research about the rationalisation of traditions "into a coherent identity" (Bronner 1998: 1), I here attempt to scrutinise how heterogeneous Sámi traditions are organised "into a coherent identity".

It should not be surprising to see such a use of the concept of tradition in Sámi revitalisation initiatives. In this specific context, efforts for building a sustainable future legitimate the references to something that has always existed, or that might have been erased or forgotten, but used to be part of a genuine culture. An emphasis on the stability of traditions underscored by Noyes (2009) contributes to the strengthening of Sámi culture and identity. Traditionalisation has implications for identity management, and engaging in traditional Sámi practices means engaging with core cultural values (cf. Jackson 2008). Beyond ethnicity, knowledge of 'traditions' and skills in traditional practices are essential to the recognition of community membership. In addition, the official status of tradition (e.g., by $\mathrm{UNESCO}^{21}$ ) entails the protection of practices on both national and international levels. Moreover, issues of ownership associated with a specific group are brought up when discussing the origin and genuineness of traditional practices. In other words, traditionalisation ensures the future of these practices and gives them stability.

The results presented here indicate that the process of identity management currently occurring in Sápmi follows certain tendencies and movements that can be observed elsewhere. For example, storytelling and food have been emphasised in previous research as cultural and/or regional traditions in various contexts (cf., for instance, Sobol 1999; Cruikshank 1998; Leitch 2003). Globalisation is another force that contributes to a global discourse that is not about homogenisation but is rather "a way of organizing heterogeneity" (Eriksen 2007: 10). Globalisation contributes to the processes of traditionalisation through the emphasis of uniqueness, and is a global discourse "that entails a great number of formal commonalities between ethnic groups struggling for recognition" (Eriksen 2007: 65). This emerges, for example, with the issues of "cultural heritage" and "shared customs" (ibid.). At the international level, globalisation is illustrated by UNESCO's Convention for the Safeguarding of Intangible Cultural Heritage. At the community level, the same efforts are enacted in the articulation of "the traditional". 
The context in which traditions are (re)defined is another essential element for understanding the underlying processes and forces of traditionalisation (cf. Anttonen 2005). An international discourse of cultural heritage provides authenticating strategies that can be applied on the local level. What today are considered valuable traditions in need of protection, or whose ownership is in debate, were perceived barely as forms of expressive culture or valuable traditions in Sápmi 100 years ago. The Sámi yoik, for instance, was a form of singing that was stigmatised and forbidden. Food is another tradition, the value of which has been acknowledged only recently. Through the framework of the UNESCO convention, cultural heritage has grown in importance and has become a strong argument for the revitalisation process. It legitimises a claim of authenticity and argues for the power of a cultural past.

\section{TRADITIONALISATION THROUGH INSTITUTIONALISATION: AUTHORITY AND AUTHORISATION}

The (re)definition of tradition(s) is significant for every cultural or ethnic group, but it might be even more essential for minority and indigenous people who have had to struggle to maintain their cultural traits through processes of assimilation by majority groups and governments. The meaning of the concept of tradition in indigenous contexts has been approached in previous research:

Tradition has a liberating valence in many decolonizing, indigenous, and post-Soviet societies subjected to disruptive modernizing regimes and the stigma of backwardness. In reaction to a perceived detraditionalization, new regimes will institute 'oral literature' in the curriculum, undertake active revivals that bring about a charismatic and sometimes traumatic return of presumably repressed tradition, restructure legal systems according to 'custom', reconstruct epics as the basis of national unity, and once again set out to purify traditions of foreign influences, as if romantic nationalism had never been challenged. (Noyes 2009: 242)

Similarities with what Noyes observes here can be found in the contemporary Sámi context. Among the 'new regimes' are Sámi officials whose efforts to articulate the continuity of 'traditional' practices might endanger variations and heterogeneity. Traditionalisation is enacted through the institutionalisation of 'traditional' practices.

Through the process of institutionalisation, practices can be turned into objects; this process materialises aspects of culture and behaviour into commodities that can be protected and owned. As Noyes emphasises, tradition 
can become "an object of veneration in its own right, a monument of cultural identity; its form, 'protected' from decay and corruption, becomes frozen in time" (Noyes 2009: 246-247).

The quest for tradition in indigenous contexts on the one hand, and the objectification of practices on the other hand, reveals a tension and a paradox between the vernacular and the institutional. The phenomenon identified by Noyes appears to be something that contemporary Sámi initiatives strive to challenge and counteract. Symbols of identities are articulated as practices based on specific enacted knowledge such as herding, sewing a gákti, or creating a piece of duodji.

While folk practices are empirically and practically based, they can evolve into symbols of identity within and outside a group, just as the gákti is more than just a piece of clothing today. On an institutional level, practices become the criteria for defining ethnic identity and issues of ownership (cf. Comaroff \& Comaroff 2009; Kuutma 2006; Mathisen \& Pertti 2000). As Consultant 3 observed, these criteria can also be heard in public discourses through statements about the way that a gákti is "supposed to be". In practice, a strong attachment to tradition is a requirement for possible negotiations for renewal.

The political claims behind the use and labelling of traditions and traditional practices cannot be ignored. As mentioned above, contemporary Swedish minority politics emphasises the traditional in a broad sense. Expressive culture is a form of 'otherness' that is easy to tolerate in comparison to other differences, such as different religious beliefs and practices (Blommaert \& Verschueren 1998). This is an aspect that minority groups have been eager to take advantage of, and in the Sámi case this has focused on culinary practices and handicrafts. Moreover, defining traditions and traditional practices is a way for a group to take control over the production of knowledge about their own history. Community-based traditionalisation can, therefore, constitute an empowerment strategy (cf. Servaes 1999; White 2004: 20).

The issue of empowerment needs to be understood in light of the identification of the agents and forces behind revitalisation. As Bronner (2011) points out, the examples of practices that are identified as "traditional" need to be understood in terms of authority and control:

These examples remind us of the negotiation inherent when traditions are enacted, including the questions of who dictates which traditions will be followed, how they will be followed, how traditions may be discouraged or even proscribed by external forces (i.e., authority), and how traditions are adapted by their participants (i.e., control). (Bronner 2011: 136) 
The network of driving forces behind the process of redefinition of the meaning of tradition is intricate. Although this study is based on websites produced by, or in collaboration with, Sámi officials and institutions, the dynamics of production are complex. Representatives of officials, the media, and private initiatives are interwoven in the articulation of the traditional that results in a coherent and concordant discourse (cf. Howard 2008).

The issue of authority stands in relation to the issue of responsibility and entitlement when we study the articulation of traditional practices. Noyes underscores the importance of responsibility in the transfer of tradition: "[R]esponsibility is assumed toward both past and future as personified in particular individuals. The receiver must respect, but the giver must let go" (Noyes 2009: 248). Previous research also reminds us of the distribution of responsibility. The question of who is entitled to tell a story, perform traditional practices, or convey traditional knowledge (cf. Briggs 1988; Shuman 2010) still needs to be further investigated in a Sámi context. The role of the media and politicians appears central, for instance, for the implementation of the North Sámi term árbediehtu (traditional knowledge), a term that has recently been actualised by the Sámi Parliament (Sametinget 2010).

\section{A DOUBLE-EDGED PROCESS}

The approach to the concept of 'tradition' in Sámi contemporary discourse that has been described in this work allows us to identify some of the processes and forces involved in deciding which practices are labelled as traditions. This study indicates that a quest for tradition is in negotiation with the heterogeneity of Sámi identities and that this is reinforced and enacted by globalisation processes.

The selected data in this study were produced by Sámi institutions and officials, but the 'traditional' practices that these discourses refer to are vernacular in their origin. The emergence of such expressions through official conduits contributes to traditionalisation by reinforcing the authoritative quality of 'tradition'.

In the examples discussed in this article, Sámi self-representation delivers a one-sided picture, whereas the variation in duodji and traditional knowledge is infinite. My call for cautiousness when approaching representations of traditions does not question the importance of these elements for Sámi culture through time, nor does it question their significance today. Instead, such an approach encourages reflection upon changes to the nature of their importance 
in relation to contemporary social and political contexts and bears in mind the possibilities for exclusion in the processes discussed above.

Based on these contemporary Sámi examples and on a discussion of the explicit goals and implicit consequences of traditionalisation, this study shows how the labelling of practices as 'tradition' acts on two levels. First, it acts by including, i.e., it creates a sense of belonging to a community. However, the second way of acting is exclusionary, i.e., the process dictates the normative aspect of 'tradition'. It creates not only an insider/outsider dichotomy, but also a boundary between those in the community who possess knowledge of the practices and those who do not. Thus, traditionalisation is a double-edged process. Due to the normative implications of the concept of tradition, attempts to contribute to cultural production and revitalisation might, in fact, counteract the same efforts.

By examining the emic applications of the concept, this study emphasises the processual and consequential aspects of 'tradition'. It problematises explicit practices and discusses implicit factors behind traditionalisation within the specific case of the Sámi in Sweden in a contemporary context. Similar issues are under debate in other minority and indigenous communities, and my hope is to contribute with this study to a critical understanding of the applications and effects of traditionalisation.

\section{NOTES}

1 In the Swedish Sámi Parliament act, "Sámi" refers to an individual who has or has had Sámi as the language at home, or who has or has had a parent, grandparent, or great-grandparent who had Sámi as the language at home (Sámi Parliament Act 1992: 1433). Equivalent definitions have been enacted in Norwegian and Finnish legislations.

2 The survey, distributed electronically among users of Sámi-produced websites, asked about expectations and experiences in relation to explicit goals expressed in minority politics, such as visibility, identity, representation, and transmission of traditions. Regarding the main expectations that the users of Sámi websites have for sites for children, 39\% (the highest percentage) chose the option "to convey culture and traditions" followed by "entertainment" and "language acquisition", both with $26.8 \%$ of the respondents. Another question in the survey asked the users to evaluate to what degree the websites succeeded in their explicit goals. To the statement that the Sámi websites succeeded in "conveying Sámi traditions", $69.8 \%$ selected the options "to some extent" or "to a lesser extent". The high number of skeptical answers to this question indicates that the Internet's ability to contribute to the continuity of traditions has yet to be proven. The survey was conducted in February and March of 2011. 
${ }^{3}$ Interviews were conducted in order to include the perspective of content producers and cultural workers. The main focus was not on "the traditional", but the topic came up in discussion in six of the interviews. Although this sample might be too small for valid conclusions, it provides us with valuable comments from members of the Sámi community.

4 The term "consultant" (cf. Peoples \& Bailey 2011: 102) emphasises the reciprocity of the relationship between the researcher and the interviewee.

5 Author's translation (from Swedish).

6 The selected websites are in Swedish, North Sámi, and Lule Sámi.

7 For instance, http://www.eng.samer.se/servlet/GetDoc?meta_id=1094, last accessed on January 27, 2014.

8 http://www.eng.samer.se/servlet/GetDoc?meta_id=1094, last accessed on January 27, 2014.

9 For instance, http://www.samer.se/1077, last accessed on January 27, 2014.

${ }^{10}$ E.g., Bevarande av det samiska kulturarvet, Ájtte 2008, Duoddaris 24.

${ }^{11} \mathrm{http}: / / \mathrm{www}$.visitsapmi.com/en/Facts/Way-of-life/Arts--Crafts/Tradition-anddevelopment-at-the-same-time/, last accessed on January 27, 2014.

12 The majority of students at Sámi language courses are of Sámi origin. However, a more precise estimation about the web visitors would require more extensive user data.

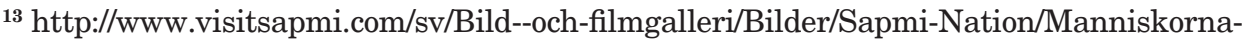
i-Sapmi/Har-du-hort-att/, last accessed on January 27, 2014.

${ }^{14}$ Author's translation.

${ }^{15} \mathrm{http}: / /$ www.slowfood.com/, last accessed on January 27, 2014.

${ }^{16} \mathrm{http}: / / w w w . r e n l y c k a . s e / r e n l y c k a \_p r e s \_e n g \_u t s k r . p d f$, last accessed on January 27, 2014.

${ }^{17}$ Author's translation. For more information about the project in English, see http:// www.renlycka.se/renlycka_pres_eng_utskr.pdf, last accessed on January 27, 2014.

$18 \mathrm{http} / / /$ www.sapmiawards.com/en/about-sapmi-awards/, last accessed on January 27, 2014.

${ }^{19}$ For further information about the programme, see http://www.jokkmokksmarknad. se/, last accessed on January 27, 2014.

${ }^{20}$ National programme on local and traditional knowledge concerning the conservation and sustainable use of biological diversity.

${ }^{21}$ UNESCO Convention for the Safeguarding of Intangible Cultural Heritage. 


\section{REFERENCES}

Anttonen, Pertti J. 2005. Tradition through Modernity: Postmodernism and the NationState in Folklore Scholarship. Helsinki: Finnish Academy of Science \& Letters.

Bjørklund, Ivar 2000. Sápmi: Becoming a Nation: The Emergence of a Sami National Community. Tromsø: Troms $\emptyset$ University Museum.

Blommaert, Jan \& Verschueren, Jef 1998. Debating Diversity: Analysing the Discourse of Tolerance. London: Routledge.

Briggs, Charles L. 1988. Competence in Performance: The Creativity of Tradition in Mexicano Verbal Art. Philadelphia: University of Pennsylvania Press.

Bronner, Simon J. 1998. Following Tradition: Folklore in the Discourse of American Culture. Logan, Utah: Utah State University Press. Available at http:// digitalcommons.usu.edu/cgi/viewcontent.cgi?article=1064\&context=usupress pubs, last accessed on January 29, 2014.

Bronner, Simon J. 2011. Explaining Traditions: Folk Behavior in Modern Culture. Lexington: The University Press of Kentucky.

Christophe, Jacqueline \& Boëll, Denis-Michel \& Meyran, Régis 2009. Du folklore à l'ethnologie. EMSH.

Cocq, Coppélie 2008. Revoicing Sámi Narratives: North Sámi Storytelling at the Turn of the 20th Century. Umeå: Sámi Studies, Umeå University. Available at http:// umu.diva-portal.org/smash/get/diva2:141498/FULLTEXT01, last accessed on January 29, 2014.

Cocq, Coppélie 2013a. Savoirs traditionnels et traditions de recherche: Le folklore comme instrument politique et arme idéologique. In: K. Andersson (ed.) L’image du Sápmi 2. Örebro: Örebro Universitet.

Cocq, Coppélie 2013b. Anthropological Places, Digital Spaces and Imaginary Scapes: Packaging a Digital Samiland. Folklore, Vol. 124, No. 1, pp. 1-14. http://dx.doi. org/10.1080/0015587X.2012.753695.

Cocq, Coppélie 2013c. From the Árran to the Internet: Sami Storytelling in Digital Environments. Oral Tradition, Vol. 28, No. 1, pp. 125-142. Available at http:// journal.oraltradition.org/files/articles/28i/07_28.1.pdf.

Comaroff, John L. \& Comaroff, Jean 2009. Ethnicity, Inc. (Chicago Studies in Practices of Meaning). Chicago: University Of Chicago Press.

Cruikshank, Julie 1998. The Social Life of Stories: Narrative and Knowledge in the Yukon Territory. Lincoln: University of Nebraska Press.

Deloria, Vine Jr. 1998. Comfortable Fictions and the Struggle for Turf: An Essay Review of the Invented Indian: Cultural Fictions and Government Policies. In: D. A. Mihesuah (ed.) Natives and Academics: Researching and Writing about American Indians. Nebraska: University of Nebraska Press, pp. 65-83.

Elenius, Lars 2006. Nationalstat och minoritetspolitik. Samer och finskspråkiga minoriteter $i$ ett jämförande nordiskt perspektiv. [Nation-State and Minority Politics: Sami and Finnish-Speaking Minorities in a Comparative Nordic Perspective.] Lund: Studentlitteratur.

Eriksen, Thomas H. 2007. Globalization: The Key Concepts. New York: Berg Publishers. Glassie, Henry 1995. Tradition. The Journal of American Folklore, Vol. 108, No. 430, pp. 395-412. http://dx.doi.org/10.2307/541653. 
Grenoble, Leonore A. \& Whaley, Lindsay J. 2006. Saving Languages: An Introduction to Language Revitalization. Cambridge: Cambridge University Press.

Hafstein, Valdimar T. 2009. Glímt við fortíðina: Pjóðarípróttin, menningararfurinn og karlmannslíkaminn. [Wrestling with the Past: National Sport, Cultural Heritage, and the Male Body.] Pjóðarspegilinn. Rannsóknir í Félagsvísindum IX. [Research in Social Sciences IX.] Reykjavík: University of Iceland Press.

Handler, Richard \& Linnekin, Jocelyn 1984. Tradition, Genuine or Spurious. The Journal of American Folklore, Vol. 97, No. 385, pp. 273-290. http://dx.doi. org/10.2307/540610.

Hine, Christine M. 2000. Virtual Ethnography. London \& Thousand Oaks \& New Dehli: Sage Publications Ltd.

Howard, Robert G. 2008. Electronic Hybridity: The Persistent Processes of the Vernacular Web. Journal of American Folklore, Vol. 121, No. 480, pp. 192-218. doi: 10.1353/jaf.0.0012.

Hyltén-Cavallius, Charlotte 2007. Traditionens estetik: spelet mellan inhemsk och internationell hemslöjd. [The Aesthetics of Tradition: The Interplay between Domestic and International Handicraft.] Stockholm: Carlsson Bokförlag.

Hymes, Dell 1975. Folkore's Nature and the Sun's Myth. The Journal of American Folklore, Vol. 88, No. 350, pp. 345-369. doi: 10.2307/538651.

Jackson, Jason B. 2008. Traditionalization in Ceremonial Ground Oratory: Native American Speechmaking in Eastern Oklahoma. Midwestern Folklore, Vol. 34, No. 2, pp. 3-16.

Korhonen, Olavi 2008. Är lappologin död? [Is Lappology Dead?] Oknytt, Vol. 3-4, pp. 6-17. Available at http://www.johannordlandersallskapet.se/oknytt/2008_3-4.pdf, last accessed on March 24, 2014.

Kozinets, Robert V. 2011. Netnografi. Etnografiska undersökningar på nätet. [Nethnography: Doing Ethnographical Research Online.] Lund: Studentlitteratur.

Kuutma, Kristin 2006. Changing Codified Symbols of Identity. FF Network for the Folklore Fellows, Vol. 31, pp. 7-11, 14. Available at FFNetwork31.pdf, last accessed on January 31, 2014.

Kvist, Roger 1992. Swedish Saami Policy, 1550-1990. In: R. Kvist (ed.) Readings in Saami History, Culture and Language III, Vol. 14. Umeå: Center For Artic Cultural Research, Umeå University, pp. 66-77.

Leitch, Alison 2003. Slow Food and the Politics of Pork Fat: Italian Food and European Identity. Ethnos: Journal of Anthropology, Vol. 68, No. 4, pp. 437-462. http:// dx.doi.org/10.1080/0014184032000160514.

Lundmark, Lennart 2008. Stulet land: svensk makt påsamisk mark. [Stolen Land: Swedish Power on Sami Land.] Stockholm: Ordfront Förlag.

Mathisen, Stein R. 2000. Travels and Narratives: Itinerant Constructions of a Homogenous Sami Heritage. In: Pertti Anttonen \& Anna-Leena Siikala \& Stein R. Mathisen \& Leif Magnusson (eds.) Folklore, Heritage Politics and Ethnic Diversity: A Festschrift for Barbro Klein. Botkyrka: Multicultural Centre, pp. 179-205.

Mould, Tom 2005. The Paradox of Traditionalization: Negotiating the Past in Choctaw Prophetic Discourse. Journal of Folklore Research: An International Journal of Folklore and Ethnomusicology, Vol. 42, No. 3, pp. 255-294. http://dx.doi. org/10.2979/JFR.2005.42.3.255. 
Nordin-Jonsson, Åsa 2010. Árbediehtu: samiskt kulturarv och traditionell kunskap. [Árbediehtu: Sami Cultural Heritage and Traditional Knowledge.] Uppsala: CBM \& Sametinget.

Noyes, Dorothy 2009. Tradition: Three traditions. Journal of Folklore Research: An International Journal of Folklore and Ethnomusicology, Vol. 46, No. 3, pp. 233-268. http://dx.doi.org/10.2979/JFR.2009.46.3.233.

Peoples, James \& Bailey, Garrick 2011. Humanity: An Introduction to Cultural Anthropology. Belmont, CA: Wadsworth Publishing.

Pico Larsen, Hanne 2011. Performing Tasty Heritage: Danish Cuisine and Playful Nostalgia at Restaurant Noma. Ethnologia Europaea, Vol. 40, No. 2, pp. 90-103.

Pietikäinen, Sari 2008. Sami in the Media: Questions of Language Vitality and Cultural Hybridisation. Journal of Multicultural Discourses, Vol. 3, No. 1, pp. 22-35. http:// dx.doi.org/10.2167/md088.0.

Porsanger, Jelena 2004. An Essay about Indigenous Methodology.Nordlit, Vol. 15, pp. 105-120. Available at http://websim.arkivert.uit.no/getfile.php\%3fPageId=977\%26FileId=188, last accessed on February 3, 2014.

Qvigstad, Just Knut 1928. Lappiske eventyr og sagn II. [Sami Legends and Tales.] Oslo: Instituttet for sammenlignende kulturforskning.

Ruong, Israel 1981. Samerna: identitet och identitetskriterier. [The Sami: Identity and Criteria of Identity.] Nord Nytt: Nordisk tidsskrift for folkelivsforskning, Vol. 11, pp.17-32.

Scheller, Elisabeth \& Vinka, Mikael (forthcoming). The Saami Languages. In: Barents encyclopedia.

Schram, Kristinn 2010. Obscurity as Heritage: The Porrablót Revisited. In: Pjóðarspegilinn. Rannsóknir i Félagsvísindum XI. [Research in Social Sciences IX.] Reykjavík: University of Iceland Press, pp. 134-140. Available at http://skemman.is/en/ stream/get/1946/6841/18618/3/134-140_KristinnSchram_FELMANbok.pdf, last accessed on February 3, 2014.

Servaes, Jan 1999. Communication for Development: One World, Multiple Cultures. Cresskill, NJ: Hampton Press.

Shuman, Amy 2010. Other People's Stories: Entitlement Claims and the Critique of Empathy. Champaign, IL: University of Illinois Press.

Smith, Linda T. 1999. Decolonizing Methodologies: Research and Indigenous Peoples. London \& New York: Zed Books.

Sobol, Joseph D. 1999. The Storytellers' Journey: An American Revival. Urbana, IL: University of Illinois Press.

Stålnert, Birgitta 2011. Jakten på den försvunna samiska dansen: det här är berättelsen om hur koreografen Ola Stinnerbom till slut fann bevisen på att det verkligen har funnits en samisk danstradition. [The Quest for the Ost Sami Dance: This is the Story of How the Choreographer Ola Stinnerbom Eventually Found Evidence That There Really Has Been a Sami Dance Tradition.] Umeå: Centrum för samisk forskning, Umeå Universitet.

Toelken, Barre 1996. Dynamics of Folklore. Logan, UT: Utah State University Press.

Turi, Johan 1931. Sámi deavsttat. Duoddaris. [Sámi Texts: From the Mountains.] Jokkmokk: Sámi Girjjit. 
Turi, Johan 2010 [1910]. Muitalus sámiid birra. [An Account of the Sámi.] Edited by M. Svonni. Kárášjohka: ČálliidLágádus.

Utsi, Per M. 2007. Traditionell kunskap och sedvänjor inom den samiska kulturen. [Traditional Knowledge and Practices within the Sami Culture.] Uppsala: Sametinget, Kiruna and Centrum för biologisk mångfald. Available at http://www. slu.se/Global/externwebben/centrumbildningar-projekt/centrum-for-biologiskmangfald/Dokument/publikationer-cbm/cbm-skriftserie/skrift18.pdf, last accessed on February 3, 2014.

White, Robert A. 2004. Is "Empowerment" the Answer?: Current Theory and Research on Development Communication. International Communication Gazette, Vol. 66, No. 1, pp. 7-24. doi:10.1177/0016549204039939.

\section{REPORTS}

Ájtte 2008 = Bevarande av det samiska kulturarvet: Programme 2008-2012. [Preservation of the Sami Cultural Heritage.] Duoddaris 24. Available at http://www.ajtte. com/ny/wp-content/uploads/2009/05/bev_samiskt_kulturarv-t.pdf, last accessed on February 4, 2014.

Council of Europe 1992. European Charter for Regional or Minority Languages. Available at http://conventions.coe.int/Treaty/en/Treaties/Html/148.htm, last accessed on February 4, 2014.

Council of Europe 1995. Framework Convention for the Protection of National Minorities. Available at http://conventions.coe.int/Treaty/en/Treaties/Html/157.htm, last accessed on February 4, 2014.

Government Offices of Sweden 2009. Lag (2009:724) om nationella minoriteter och minoritetsspråk. [Law on National Minorities and Minority Languages.] Available at http://www.notisum.se/rnp/sls/lag/20090724.HTM, last accessed on February $4,2014$.

Government Offices of Sweden 2009. Från erkännande till egenmakt - regeringens strategi för de nationella minoriteterna. [From Recognition to Empowerment: Government Strategy for National Minorities.] Government bill 2008/2009:158. Available at http://www.regeringen.se/content/1/c6/12/27/69/fc387549.pdf, last accessed on March 24, 2014.

Sametinget [Sámi Parliament] $2010=$ Árbediehtu. Sametingets policydokument för tra ditionell kunskap. [Árbediehtu. The Sámi Parliament's Policy Programme for Traditional Knowledge.] Available at http://www.sametinget.se/26119, last accessed on February 4, 2014.

Sametinget [Sámi Parliament] $2011=$ Verksamhetsplan. [Plan of Activities.] Available at http://www.sametinget.se/29871, last accessed on February 4, 2014.

Sametinget [Sámi Parliament] n.d. = Sametingets kulturpolitiska handlingsprogram 2010-2013. [Cultural and Educational Policy Programme 2010-2013.] Available at http://www.sametinget.se/29385, last accessed on February 4, 2014. 
SSR [Swedish Reindeer Herders Association] n.d. = Kartläggning av det samiska kulturlandskapet. [Mapping the Sámi Cultural Landscape.] Available at http:// www.sapmi.se/mala_2.pdf, last accessed on February 4, 2014.

UNESCO 2001 = Universal Declaration on Cultural Diversity. Available at http:// ec.europa.eu/avpolicy/docs/ext/multilateral/gats/decl_en.pdf, last accessed on February 4, 2014.

UNESCO 2003 = Convention for the Safeguarding of the Intangible Cultural Heritage. Available at http://www.unesco.org/culture/ich/index.php?pg=00006, last accessed on February 4, 2014.

\section{INTERVIEWS}

Consultant 1: female, teacher. Interview by the author on 21.01.2011.

Consultant 3: male, cultural worker. Interview by the author on 06.03.2011.

Consultant 4: male, cultural worker. Interview by the author on 14.03.2011.

Consultant 5: female, cultural worker. Interview by the author on 16.03.2011.

\section{ONLINE RESOURCES}

Ájtte, Swedish Mountain and Sami Museum, www.ajtte.com, last accessed on February 4, 2014.

Gaaltije, South Sámi Cultural Centre, www.gaaltije.se, last accessed on February 4, 2014.

Gulahalan. Utbildningsradion/Samernas utbildningscentrum. [the Swedish Broadcasting Company / Sámi Educational Centre.] www.ur.se/gulahalan, last accessed on February 4, 2014.

Jokkmokks marknad. [Jokkmokk's Market.] http://www.jokkmokksmarknad.se/, last accessed on February 4, 2014.

Renlycka. [Reindeer Luck.] www.renlycka.se, last accessed on February 4, 2014.

Sámásta. www.ur.se/samasta, last accessed on February 4, 2014.

Samiskt informationcentrum. [Sámi Information Centre.] www.samer.se, last accessed on February 4, 2014.

Sápmi Awards. http://www.sapmiawards.com/en, last accessed on February 4, 2014.

Slow Food. http://www.slowfood.com/, last accessed on February 4, 2014.

Tema modersmål. [Project Mother Tongue.] http://modersmal.skolverket.se/samiska/, last accessed on February 4, 2014.

VisitSápmi. www.visitsapmi.com, last accessed on February 4, 2014. 